\title{
Universiteit
}

Leiden

The Netherlands

\section{Protoclusters associated with distant radio galaxies}

Venemans, B.P.

\section{Citation}

Venemans, B. P. (2005, April 27). Protoclusters associated with distant radio galaxies. Retrieved from https://hdl.handle.net/1887/2708

Version: $\quad$ Corrected Publisher's Version

License: $\quad$ Licence agreement concerning inclusion of doctoral thesis in the Institutional Repository of the University of Leiden

Downloaded from: https://hdl.handle.net/1887/2708

Note: To cite this publication please use the final published version (if applicable). 


\section{Stellingen}

behorend bij het proefschrift

\section{Protoclusters Associated with Distant Radio Galaxies}

1. Distant luminous radio galaxies are good tracers of protoclusters.

Chapters 2, 3, 4 and 5 of this thesis

2. The population of $\operatorname{Ly} \alpha$ emitters in forming clusters is associated with young galaxies.

Chapters 3, 6 and 7 of this thesis

3. The narrow-band imaging technique is the most efficient way to find galaxy overdensities in the early Universe.

Chapters 2, 3, 4 and 5 of this thesis

4. The total metal production in forming clusters is sufficient to explain the metal content of the intracluster medium at $z \sim 1$.

Chapter 3 of this thesis

5. Radio galaxies are "freaks".

Stelling 5, M. Reuland, PhD thesis

6. Gedetailleerdere waarnemingen van sterrenstelsels leiden niet altijd tot meer inzicht.

7. De sterrenkunde is nu meer gebaat bij krachtigere instrumenten dan bij grotere telescopen.

8. De interpretatie van "hoge roodverschuiving" is de laatste jaren net zo snel veranderd als onze kennis van het vroege Heelal.

9. De beste ingevingen krijg je als je op het punt staat van het werk naar huis te gaan.

10. Niets doen kan je pas echt waarderen als je veel werk hebt liggen.

11. Een chaotisch bureau is een stuk overzichtelijker dan een net bureau.

Leiden, 27 april 2005

Bram Venemans 